G. W. Colenutt, of Ryde, Mr. H. St. Barbe, of Lymington, and Mr. J. Duce, for much valuable assistance both before and during the excursion, and also Mr. Clement Reid, of H.M. Geological Survey, who, by his practical advice based on intimate knowledge of the beds, and by his many useful suggestions, materially aided them in preparing the details of a somewhat difficult programme. It only remains to add that the weather throughout the excursion was perfect.

\title{
REFERENCES.
}

Geological Survey Map, New Series (Special Sheet), Isle of Wight.

I846. PRESTwICH, J.- "On the Tertiary or Supracretaceous Formations of the Isle of Wight, etc." Quart. Gourn. Geol. Soc., vol. ii, p. 223.

1862. Fister O.-- "On the Bracklesham Beds of the Isle of Wight Basin." Quart. Fourn. Geol. Soc, vol. xviii, p. 65.

1879. Gardner, J. S.- "On the Britisn Eocenes and their Deposition." Pro. Geol. Assoc, vol. vi, p. 83.

1880. JuDD, J. W.- "On the Oligocene Strata of the Hampshire Basin." Quart. Fourn. Geol. Soc, vol. xxxvi, p. I 37 .

188I. KeEPING, H, and TAWneY, E. B,- "On the Beds at Headon Hill and Colwell Bay, in the Isle of Wight." Quart. Fourn. Geol. Soc., vol. xxxvii, p. 85 .

I888. GaRDner, J. S., KeEPING, H., and Monckton, H. W.-" The Upper Eocene, comprising the Barton and Upper Bagshot Formations." Quart. Fourn. Geol. Soc., vol. xliv, p. 578.

r88g. Bristow, H. W., Reid, C., and Strahan, A.- "The Geology of the Isle of Wight" (and Edition). Mem. Geol. Survey.

For previous excursions to the Isle of Wight see "Record' of Excursions pp. 298-304, and Proc. Geol. Assoc., vol. xii, p 145.

\section{EXCURSION TO CHARLTON (KENT).}

\author{
Saturday, 20Th APRIL, i 895. \\ Director:-T. V. Holmes, F.G.S. \\ (Report by the DIRECTOR.)
}

On arrival at Chariton, the party at once proceeded to the great pit a few yards east of the Railway Station which has been the scene of so many excursions of the Association, the earliest having taken place in August, $\mathrm{I} 860$. This pit, from which so many thousands of tons of Chalk and Thanet Sand have been removed, has now ceased to be worked; the line of railway thence to the river has disappeared; and the entrance is now not from the Woolwich Road but by a road marked private, which turns eastward from a point about 50 yards south of the Charlton Railway Station. We visited it by kind permission of Mr. Ellis, the present proprietor.

On entering the pit, the Director explained the reason of the existence of the Lower Tertiary escarpment, in which this pit is one of many sections. The Chalk (he remarked) to which the overlying JULY, 1895.] 


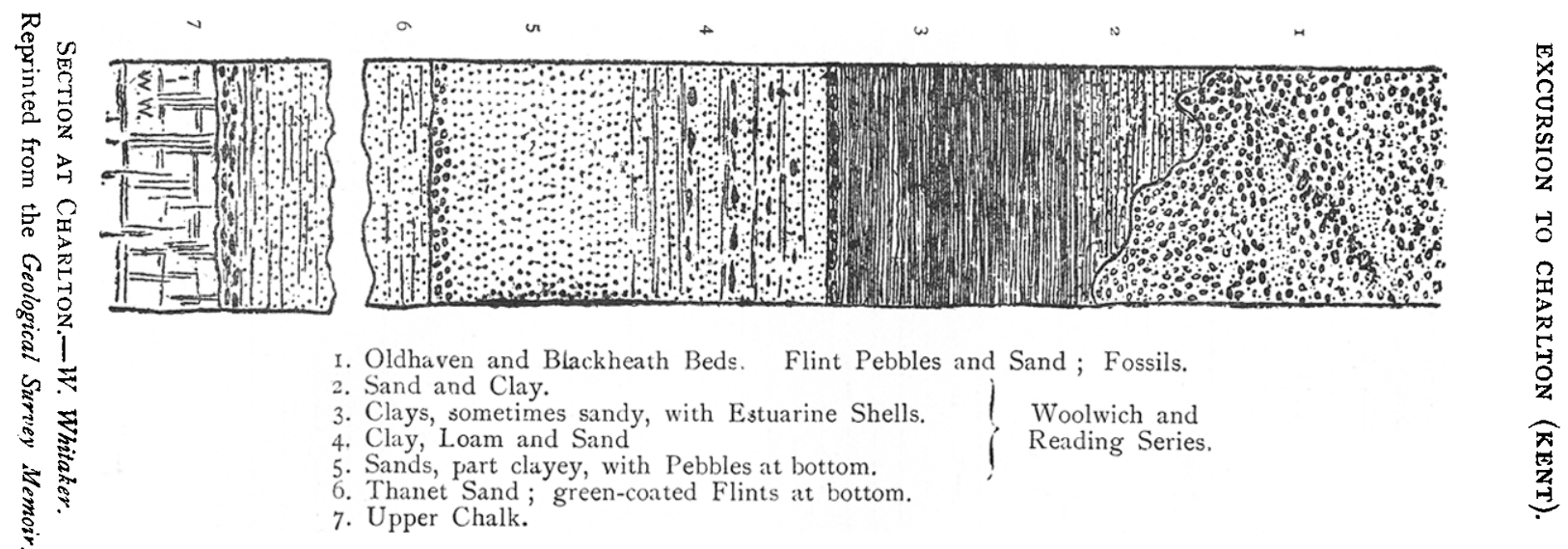


beds were practically conformable, had a northerly dip from the North Downs and became covered more or less by Tertiary Beds in northern Kent. North of the Thames it emerged from beneath the Tertiary rocks in Hertfordshire and N.W. Essex, its dip being there southerly. But, in addition, there is a local uprise of the Chalk and the overlying Tertiaries along the valley of the lower Thames, so that at Lewisham, Westcombe Park, Charlton, Greenhithe, Gravesend, and Cliffe, the Chalk is either lying flat or has a slight southerly dip. And a visit to the new railway from Grays Thurrock to Romford, on the Essex shore, showed that where the Chalk is cut through, between West 'Thurrock and Stifford, it has, with some slight undulations, a small general northerly dip. There were two faults in the Charlton neighlourhood, each having a downthrow to the north. One having a general direction from S.W. to N.E., could be seen at St. John's Railway Station, where 1t threw down the Thanet Sand against the Chalk. It appeared to increase in size towards the Northeast. At Loampit Hill, Lewisham, Blackheath Hill Railway Station, the Chalk-pits at Westcombe Park, and that in which they then were, the top of the Chalk was 30 or 40 feet abuve Ordnance datum. But at Messrs. Lovibond's Brewery, Greenwich, which stands on old river-gravel, the top of the Chalk was 8o feet below the surface, at the Royal Naval College, which is also on river-gravel, it was 124 feet, and in East Street, on similar strata, 159 feet to the Chalk.* On the other hand the Chalk was only 30 feet beneath the surface at a well at the Greenwich Workhouse Infirmary, which was evidently on the southerly, or upthrow, side of the fault, the surface stratum being river-gravel. The height of the surface in each of the four spots mentioned was much the same, any difference not probably exceeding io to ${ }_{5}$ feet. The other fault was one with a nearly east and west range at the foot of the Lower Tertiary escarpment between Plumstead and Erith. If it had continued to exist eastward, it would probably have been seen crossing the Grays and Romford railway between West Thurrock and the Mardyke, but no signs of it appeared there. These faults were not in any way a cause of the local uprise of the Chalk, which was as evident at Purfleet, Gravesend, and Cliffe as at Greenwich, though no faults were known or suspected at the three places lower down the Thames Valley.

Mr. F. C. J. Spurrell had brought with him some specimens of the mineral allophane, which was first found at that pit many years ago, and described by the late Prof. John Morris. He kindly distributed these specimens among the members present, and mentioned that this mineral had always been found in little fissures in the Chalk close to its junction with the Thanet Sand.

* See Whitaker's Memoir, The Geolosy of London and Part of the Thames Valley Vol. ii, pp. 72-3.

JULY, 1895.] 
One of the party was fortunate enough to find a fine lump of allophane (a hydro-silicate of alumina) in the position indicated.

It was not easy to ascend higher in this pit than the lower beds of the Thanet Sand, so after spending some time in collecting Upper Chalk fossils, the party departed in an easterly direction and entered another pit a few yards away, in the side of the hill which stands out like a promontory between the Charlton pit just visited and the new recreation ground for Woolwich known as Maryon Park. In the western flank of this hill, which juts out to the north, the uppermost beds of the Chalk and the Thanet Sand are well shown, and the Woolwich Beds and Blackheath Pebble Beds are almost equally well exhibited on the eastern flank, which looks upon Maryon Park. On the top of the hill is the fragment of an old camp-not Roman, Mr. Spurrell remarked, but British, though called Roman on the new ordnance map. The greater portion once occupied the hill which stood where, owing to the removal of the Chalk and Thanet Sand, there is now a hollow transformed into a recreation ground. From the top of the hill we had a magnificent view. Southward it was bounded by Shooter's Hill and the well-wooded land about Old Charlton. On the north-east appeared the Essex Hills at Havering-atteBower and around Brentwood, and still further eastward arose the outlier of Bagshot Sand capped by gravel, known as Langdon or Laindon Hill.

\section{REFERENCES.}

Geological Survey Map, Sheet I, S.W. (Drift Edition).

New Ordnance Survey Map, Sheet 27 I.

1889. Whitaker, W. - "Geology of London." Mem. Geol. Survey. See also "Record of Excursions," pp. I-7.

\section{EXCURSION TO BRIGSTOCK AND GEDDINGTON.}

$$
\text { Saturday, April } 27 \mathrm{TH}, 1895 .
$$

Directors: Beeby Thompson, F.C.S., F.G.S., and W. D. Crick, F.G.S.

\section{(Report by BeEBY THOMPSON.)}

The members arrived at Corby (Weldon Station) about i I o'clock, and proceeded to examine a section of Upper Lias Clay, newly opened by the Weldon and Corby Brick Company. Owing to the recent heavy rains very little could be done here, but a few fossils were obtained, including Ammonites bifrons, Myacites donaciforme, Inoceramus, etc. The clay is micaceous, and has a capping of Northampton Sand, though the junction between the two formations is most irregular owing to slipping.

JULY, I 895.] 